\title{
Experimental lead poisoning in the baboon
}

\author{
ANTHONY HOPKINS \\ The Institute of Neurology, Queen Square, London,
}

\begin{abstract}
Hopkins, A. (1970). Brit. J. industr. Med., 27, 130-140. Experimental lead poisoning in the baboon. Twelve large and three infant baboons were poisoned by the intratracheal injection of lead carbonate in doses ranging from 50 to $135 \mathrm{mg} / \mathrm{kg}$ for 39 to 362 days. Eight baboons had one or more epileptic fits. Weakness of the limbs, believed to be of central origin, was seen in three of them. The effect of single and multiple doses of lead on the blood lead is recorded. Anaemia and punctate basophilia were not found. Measurements of nerve conduction velocity, electromyography and histological examination showed no abnormality of the peripheral nerves. The different effects of lead upon different species are discussed.
\end{abstract}

There is continuing interest in the pathological and physiological basis of lead intoxication in man. The nature of lead palsy remains obscure, in spite of many observations on experimental animals. One problem is that lead produces different effects in different species. Punctate basophilia, for example, is found in the blood of lead poisoned guinea-pigs, rabbits and man, but not in cats and dogs (Key, 1924). Gombault (1880) showed that some nerve fibres of chronically poisoned guineapigs underwent a 'nevrite segmentaire periaxile', a process which is now known as segmental demyelination. In the rabbit, however, segmental demyelination is not seen, the fibres undergoing a Wallerian type of degeneration (Shimazono, 1914).

Electrophysiological studies on lead poisoned patients have been reported by a number of workers. Hausmanowa-Petrusewicz, Emeryk, Sobkowicz, Wasowicz, and Tur (1962) and Delwaide and Chantraine (1965) both report the presence of fibrillation and polyphasic potentials suggesting denervation of muscles.

Measurements of conduction velocity have been reported on a few patients with lead palsy (Preiskel, 1958; Simpson, Seaton, and Adams, 1964; Delwaide and Chantraine, 1965) but in none was there evidence of slowing of nerve conduction. Sessa, Ferrari, and Colucci d'Amato (1965) measured ulnar conduction velocity in 20 patients exposed to lead but without symptoms referable to the nervous system. The mean velocity was about $12 \mathrm{~m} / \mathrm{sec}$ less than the values obtained in healthy people in other laboratories, but the absence of reported recordings on controls by these authors, and the absence of any note of measurement of limb temperature, renders these results difficult to interpret.

Fullerton (1966) has recently studied the changes in nerve conduction velocity in guinea-pigs with lead poisoning, some of which developed mild paralysis of the hind limbs. In 17 out of $\mathbf{4 0}$ animals examined, conduction velocity fell below the normal range of 40 to $60 \mathrm{~m} / \mathrm{sec}$, in some cases to less than $20 \mathrm{~m} / \mathrm{sec}$. These changes were associated with segmental demyelination, a few fibres showing a Wallerian type of degeneration.

Because of the varying effects of lead on different species, it was decided to study the effects of lead on an experimental animal phylogenetically closer to man. This paper reports the results of measurements of nerve conduction velocity and electromyography in the lead poisoned baboon, and observations on haemoglobin, punctate basophilia and blood lead.

\section{Methods}

Twelve large baboons (Papio anubis) were studied, their weights ranging from 7.2 to $13.6 \mathrm{~kg}$. The nine female animals all showed sexual changes in the skin and so may be presumed to be older than four years. The three male baboons weighed $7 \cdot 2$ to $9.5 \mathrm{~kg}$, and, as adult male 
baboons are larger than females, the male animals studied were clearly not full grown. In addition, three infant female baboons ( $P$. anubis $2, P$. hamadryas 1$)$ were studied, their weights ranging from $2 \cdot 8$ to $3 \cdot 3 \mathrm{~kg}$. Animals were caged singly, allowed one litre of water a day and fed on a pellet diet, M.R.C. 41 B, supplemented by a daily fruit. All animals received $1,000 \mu \mathrm{g}$ of $B_{12}$ (Glaxo Laboratories) by injection monthly, to avoid the changes seen in the nerves of captive Macaca rhesus described by Oxnard and Smith (1966). All animals were retained for at least three months in the laboratory before lead intoxication was begun. During this time all animals were treated with thenium and piperazine to eliminate parasites, and had chest radiographs. Those with haemoglobin levels of less than $10 \mathrm{~g} / 100 \mathrm{ml}$ received $50 \mathrm{mg}$ of iron a day in the drinking water. These measures resulted in increases in haemoglobin of up to $5.6 \mathrm{~g} / 100$ $\mathrm{ml}$, and in weight of up to $2 \cdot 3 \mathrm{~kg}$.

Sedation was induced by intramuscular injections of phencyclidine (Sernylan, Parke, Davis and Co.), 2 $\mathrm{mg} / \mathrm{kg}$, and promazine (Sparine, John Wyeth), $1 \mathrm{mg} / \mathrm{kg}$. Intravenous pentobarbitone (Nembutal, Abbott Laboratories), $3 \mathrm{mg} / \mathrm{kg}$, was given to produce anaesthesia for the administration of lead.

After consideration of the various possible methods of administering lead, it was decided to use an intratracheal injection of a suspension of lead carbonate. Minot (1924) successfully used this method in cats, and showed that absorption was more complete from the lungs than from the gastrointestinal tract or from a subcutaneous depot. Lead carbonate was prepared as a freshly agitated suspension in sterile normal saline, and injected, under anaesthesia, through a 21 gauge needle into the trachea. The animal was then postured at about $30^{\circ}$ to the horizontal for about 15 minutes, so that the suspension trickled into one or other lower lobe. A radiograph of the chest of one animal, 15 minutes after injection, is reproduced (Fig. 1). The usual quantity given was $1 \mathrm{~g}$ in $10 \mathrm{ml}$, this being equivalent to a dose of 50 to $135 \mathrm{mg} / \mathrm{kg}$ initial weight. Smaller quantities were given to the infant baboons so that the dosage per kilogram was in the same range.

Blood was obtained by femoral venous puncture. The haemoglobin was estimated by a modified Haldane method. Blood lead was estimated on haemolysed whole blood using the method of Delves and Vinter (1966). Blood films were stained with Leishmann's stain, and 40 high-power fields were then searched for the presence of punctate basophils.

Conduction velocity in motor and sensory fibres in the median nerve was estimated under light anaesthesia by a method similar to that of McLeod and Wray (1967), and in the anterior tibial nerve using the same principles. The median and lateral popliteal nerve trunks were stimulated through subcutaneous needles placed close to the nerve trunks. Muscle action potentials were recorded through needles with the active electrode over the belly of the abductor pollicis brevis or extensor digitorum brevis muscle, the remote electrodes being placed over the tendons. All shocks were supramaximal, but care was taken to avoid spread of the stimulus to neighbouring nerves. The ascending nerve action potential (NAP) in the median nerve was recorded at the elbow on stimulation at the wrist, and in the anterior tibial

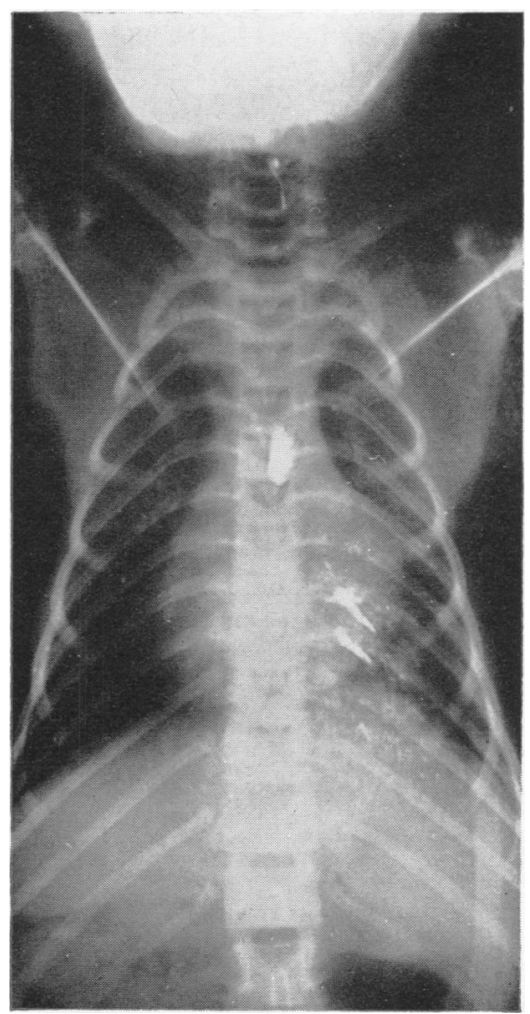

FIG. 1. Chest radiograph 15 minutes after the first

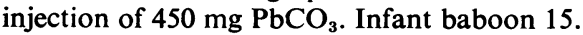

nerve at the knee on stimulation at the ankle. A sensory nerve action potential was recorded from the median nerve at the wrist on stimulation of the index finger. Full details of the placement of the electrodes and of the stimulating and recording systems are available elsewhere (Hopkins, 1968). A number of muscles were searched for fibrillation potentials, using a coaxial needle electrode (DISA 13K80). Intramuscular temperature was estimated in the forearm flexor muscles and in the anterior tibial muscles with a thermistor at a time between the measurements of motor conduction and ascending conduction in each limb. The thermistor was also used to measure temperature in a hypothenar skin fold on the hand immediately afer an estimate of sensory nerve conduction. The animal was covered with cotton wool, the room temperature was maintained above $22^{\circ} \mathrm{C}$ and on occasions a lamp would be placed near the animal's back, but no other external form of heating was employed. On two occasions the body temperature of control animals was artificially lowered by fans and icepacks to study the temperature coefficient of conduction velocity (Hopkins, 1968).

\section{Results}

The normal blood lead

Blood lead was estimated on arrival in the laboratory 
on all 15 baboons, and on 12 other healthy baboons used for other studies. The mean concentration was $11.7 \mu \mathrm{g} / 100 \mathrm{ml}$ (range $3-27$, SD $5 \cdot 5$ ), and $87 \%$ of all estimations were less than $16 \mu \mathrm{g} / 100 \mathrm{ml}$.

\section{The 'adult' baboons}

Ten animals were studied until death between 39 and 265 days after the first injection of lead, the mean survival time being 120 days. In addition two animals were killed after 336 and 362 days respectively. The clinical details of the illness of each animal are recorded in the Appendix (p. 139).

The effect of a single injection of $\mathrm{PbCO}_{3}$ on the blood lead The blood lead in one baboon (B12) was estimated at short intervals after the first injection of $1,000 \mathrm{mg}$ of lead carbonate $\left(\mathrm{PbCO}_{3}\right)(105 \mathrm{mg} / \mathrm{kg})$. Figure 2 illustrates the rise in blood lead to a peak of $310 \mu \mathrm{g} / 100 \mathrm{ml}$ by the fourth day. This level was maintained for a further seven days. The rate of decline was then approximately exponential, the blood lead remaining over $100 \mu \mathrm{g} / 100 \mathrm{ml}$ for at least 24 days.

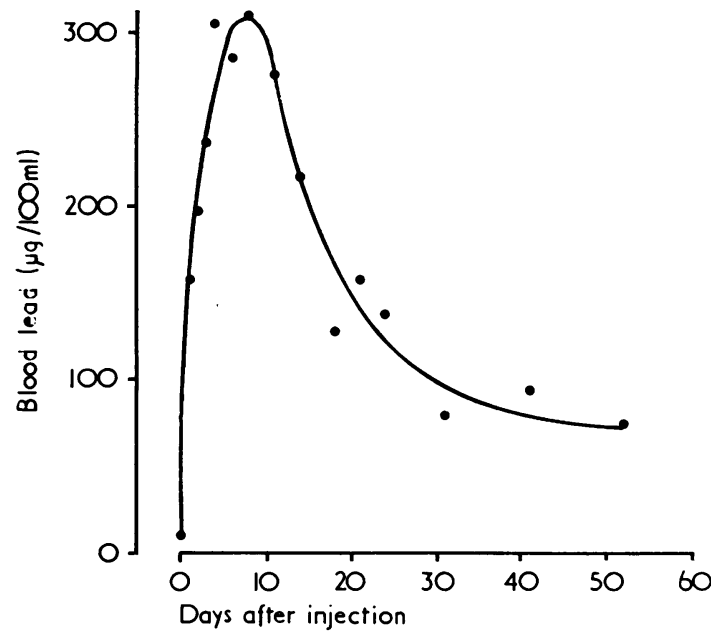

FIG. 2. The changes in the blood lead after a single injection of $1,000 \mathrm{mg} \mathrm{PbCO}_{3}$. Baboon 12 .

The effect of repeated injections of $\mathrm{PbCO}_{3}$ The results illustrated in Fig. 2 indicated that to maintain high levels of blood lead it was only necessary to give injections of $\mathrm{PbCO}_{3}$ about every three weeks. This frequency of injections was modified according to the clinical state of the animals and the values of blood lead which had previously been obtained.

Loss of weight was a striking feature in all animals, and was the most easily recognized evidence of poisoning. Five out of 12 lead poisoned animals lost $40 \%$ or more of their initial weight, the most pronounced loss being that of baboon 7 which lost $46 \%$, the weight falling from $11 \cdot 1$ to $6 \cdot 0 \mathrm{~kg}$. Five of the remainder lost $25 \%$ or more of their initial weight. This marked loss of weight contrasted with a normal appetite, which was maintained throughout the illness. No animal showed a lead line in the gum margin.

Eight out of 12 animals had one or more fits, of which 34 in all were observed. It is likely that others occurred when no observer was present. Thirteen fits and two episodes of status epilepticus were personally witnessed. All 13 fits were grand mal, but two began with a focal seizure, which soon became generalized. These focal seizures occurred on the same day in baboon 3,149 days after beginning poisoning. They began with focal twitching around the right eye, spreading to the rest of the right side of the face. During the next 15 seconds the right arm became involved, and then convulsions became generalized. Consciousness was recovered after about three minutes. Sometimes grand mal fits were precipitated by sudden movement of the animal as it tried to avoid transfer from one cage to another or whilst reaching up to take a banana. The grand mal fits were occasionally preceded by a cry. The tonic phase lasted about 15 seconds, during which the hind limbs and tail were extended. Generalized jactitation did not continue for more than a minute. Incontinence was not observed.

Paresis of limbs was noted in three animals (baboons 1, 3 and 12), but as this was associated with fits or other evidence of encephalopathy it was thought to be of central origin. Baboon 3, which had the two Jacksonian fits affecting the right face, arm and leg, developed a postictal paresis of the right limbs which lasted about 15 minutes. Baboons 1 and 12 had a longer-lasting weakness of the limbs associated in baboon 12 with frequent fits and papilloedema. Further details of all animals are recorded in the Appendix (p. 139).

The relationship between the clinical illness and level of blood lead Figure 3 illustrates the course of the clinical illness of baboons 3 and 5 . In baboon 5 poisoning was accompanied by a marked fall in weight to $62 \%$ of the initial weight, but the general condition remained very good even though at one time the blood lead was as high as $4,550 \mu \mathrm{g} / 100 \mathrm{ml}$. The haemoglobin level in this animal appears to follow approximately the changes in weight, but this was not always the case, as is shown by the chart of baboon 3. The rate of loss of weight was not related to the change in blood lead. Baboons 11 and 12 lost weight rapidly and died, the blood lead never having exceeded 500 and $630 \mu \mathrm{g} / 100 \mathrm{ml}$ respectively. However, baboons 5 and 6 were able to withstand levels of 4,550 and $2,200 \mu \mathrm{g} / 100 \mathrm{ml}$ 
BABOON 3
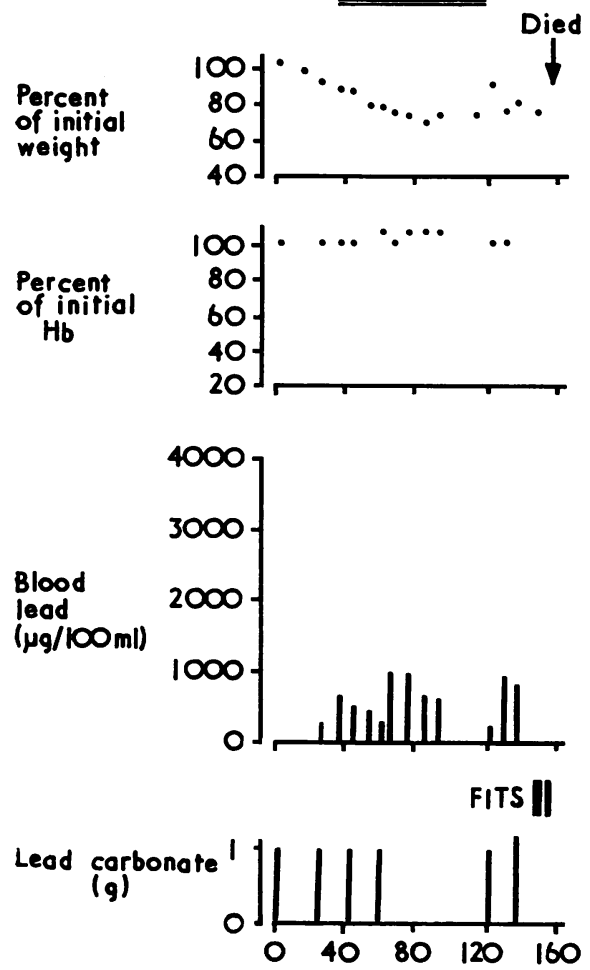

BABOON 5
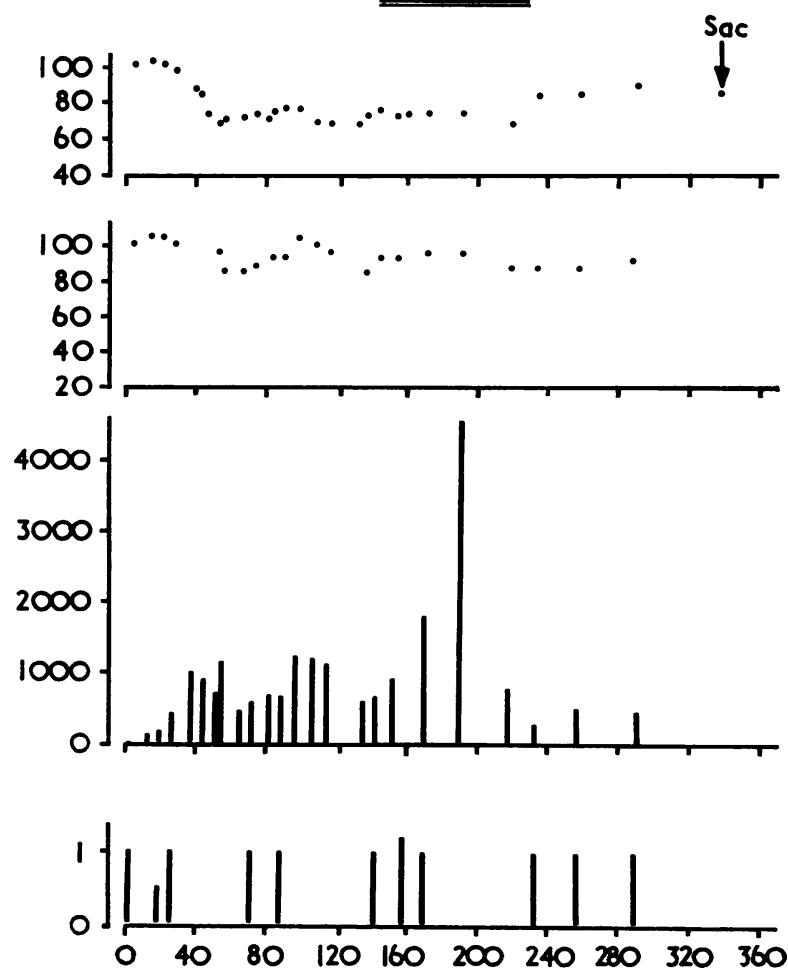

Days ofter first injection of lead

FIG. 3. Baboons 3 and 5. The changes in weight, haemoglobin and blood lead, and the occurrence of fits, after repeated injections of $\mathrm{PbCO}_{3}$.

with little or no clinical deterioration, and were eventually killed.

Inspection of the results showed that fits were particularly frequent between 4 and 11 days after an injection of lead, a time at which the blood lead reaches its peak (Fig. 2). All five baboons which began convulsing within this period died during one of a number of seizures which immediately followed. The three other baboons which convulsed did so between 23 and 29 days after the previous injection of lead, at a time when the blood lead was falling, and all survived.

Anaemia and punctate basophilia No consistent fall in haemoglobin concentration was observed. Figure 4 shows the relation between haemoglobin and blood lead plotted in a manner similar to that of Williams (1966). The results of 136 estimations of blood lead after the beginning of poisoning have been grouped into classes of $100 \mu \mathrm{g} / 100 \mathrm{ml}$ up to $1,000 \mu \mathrm{g} / 100 \mathrm{ml}$, with three further classes of $1,000-1,499,1,500-1,999$ and over $2,000 \mu \mathrm{g} / 100 \mathrm{ml}$.

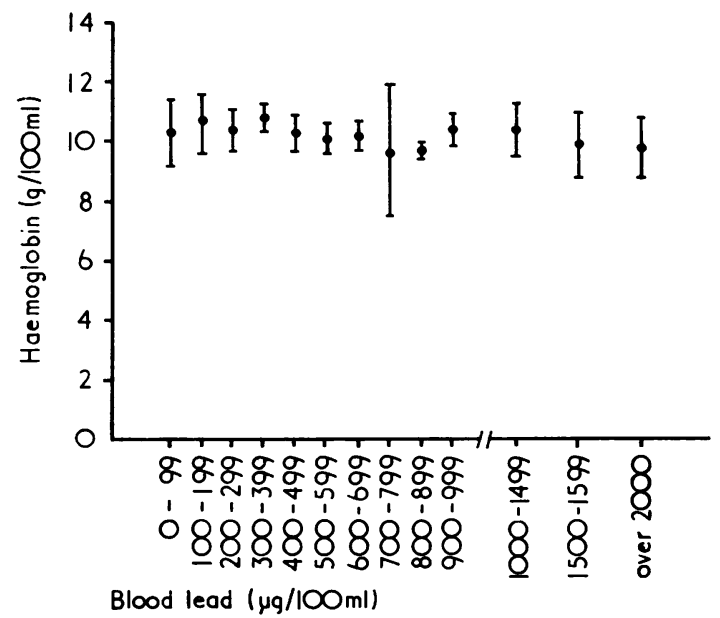

FIG. 4. The relationship between haemoglobin and blood lead. The mean \pm 2 standard deviations of all haemoglobin estimations within each blood lead class have been plotted. 
All results have been included from venepunctures when haemoglobin concentration was also estimated. The mean haemoglobin concentration and two standard deviations have been calculated for the haemoglobin estimations within each blood lead class. Figure 4 shows that there is no significant decrease in haemoglobin concentration with increasing levels of blood lead.

Punctate basophilia was not found on any one of 136 examinations.

The peripheral nervous system As noted above, the only weakness observed was associated with encephalopathy, and in no animal was there clinical evidence of a peripheral neuropathy.

Nerve conduction velocity was estimated on 16 occasions in the median and anterior tibial nerves of six baboons at times varying between 35 and 346 days after beginning injections of lead carbonate.

In all six animals examined repeatedly, no significant decrease was observed in conduction velocity in either nerve examined, or in the size of the muscle and nerve action potentials recorded. Estimates of conduction velocity recorded before intoxication, and final estimates before death or sacrifice, are compared in Table 1. Many of the lead poisoned baboons were extremely wasted, and intramuscular temperatures were consequently as much as $3^{\circ} \mathrm{C}$ lower than the initial temperatures. All velocities have therefore been adjusted to $37^{\circ} \mathrm{C}$ using temperature coefficients calculated for the median and anterior tibial nerves of the baboon (Hopkins, 1968). The mean percentage change of final velocity compared to initial velocity for all 27 observations recorded in Table 1 was only $1.07 \%$. There was no consistent decrease in the amplitude of muscle and nerve action potentials. An example of the potentials obtained is illustrated in Fig. 5, which shows the series of muscle action potentials recorded from the abductor pollicis brevis of baboon 5 , which was poisoned for nearly a year.

Motor units were recorded from extensor digitorum communis or brachioradialis, innervated by the radial nerve on six occasions (baboon 1, days 94, 105 ; baboon 4, day 123; baboon 6 , days 123,182 ; baboon 12, day 143). A temperature coefficient was not available for this nerve, but in no case was a unit found with a velocity of less than $58 \mathrm{~m} / \mathrm{sec}$. The mean velocity for all units was $67.9 \mathrm{~m} / \mathrm{sec}$, compared to a mean of $69.0 \mathrm{~m} / \mathrm{sec}$ for five units from two control animals.

Strength-duration curves were plotted for radial-

TABLE 1

Conduction Velocities of Fastest Motor Fibres and of Nerve Action Potentials in Median and ANterior Tibial Nerves of Six Baboons before and After 94 to 346 Days of Poisoning With LEAD CARBonate

\begin{tabular}{|c|c|c|c|c|c|c|c|c|c|c|c|c|c|c|}
\hline \multirow{3}{*}{ ? } & & & & & & & & \multicolumn{6}{|c|}{ Baboon } & \multirow{3}{*}{ Mean } \\
\hline & & & & & & & & 1 & 3 & & 5 & 6 & 12 & \\
\hline & & & & & & & & \multicolumn{6}{|c|}{$\begin{array}{l}\text { Interval between initial and } \\
\text { final observation (days) }\end{array}$} & \\
\hline \multicolumn{14}{|c|}{ Median nerve conduction velocity $(\mathrm{m} / \mathrm{sec})$} & \multirow[b]{7}{*}{$-1 \cdot 7$} \\
\hline Motor - initial & . & . & . & . & . & .. & . & $70 \cdot 5$ & $72 \cdot 8$ & $68 \cdot 8$ & $69 \cdot 8$ & $74 \cdot 8$ & $75 \cdot 1$ & \\
\hline - final & . & . & .. & .. & .. & .. & .. & $68 \cdot 2$ & $70 \cdot 0$ & $72 \cdot 4$ & $71 \cdot 7$ & $76 \cdot 8$ & $71 \cdot 8$ & \\
\hline $\begin{array}{l}\% \text { change } \\
\text { Ascending NAP }\end{array}$ & . & . & . & . & . & .. & . & -3 & -4 & +5 & +3 & +3 & -4 & \\
\hline - initial & .. & $\ldots$ & $\ldots$ & . & $\ldots$ & .. & . & $77 \cdot 5$ & 88.9 & $83 \cdot 4$ & $86 \cdot 1$ & $90 \cdot 4$ & $86 \cdot 5$ & \\
\hline - final & . & .. & $\ldots$ & $\ldots$ & $\ldots$ & .. & .. & $78 \cdot 5$ & $86 \cdot 0$ & $85 \cdot 7$ & $81 \cdot 0$ & $87 \cdot 7$ & $84 \cdot 5$ & \\
\hline $\begin{array}{l}\% \text { change } \\
\text { Sensory NAP }\end{array}$ & . & . & . & . & . & . & . & +1 & -3 & +3 & -6 & -3 & -2 & \\
\hline - initial & .. & .. & $\cdots$ & $\cdots$ & .. & .. & .. & - & $77 \cdot 3$ & $68 \cdot 8$ & $59 \cdot 1$ & $66 \cdot 2$ & $64 \cdot 5$ & \multirow[b]{3}{*}{$+1 \cdot 2$} \\
\hline - final & . & . & . & . & . & . & . & - & $72 \cdot 0$ & $67 \cdot 7$ & $70 \cdot 3$ & $66 \cdot 5$ & $61 \cdot 2$ & \\
\hline$\%$ change & . & . & . & . & . & . & . & - & -7 & -1 & +19 & 0 & -5 & \\
\hline \multicolumn{8}{|c|}{ Anterior tibial nerve conduction velocity $(\mathrm{m} / \mathrm{sec})$} & & & & & & & \multirow{7}{*}{$-3 \cdot 2$} \\
\hline Motor - initial & . & . & .. & . & . & .. & . & $65 \cdot 3$ & $59 \cdot 4$ & $67 \cdot 1$ & $61 \cdot 2$ & $62 \cdot 0$ & $64 \cdot 9$ & \\
\hline- final & .. & .. & .. & $\ldots$ & $\ldots$ & .. & .. & $64 \cdot 7$ & $55 \cdot 0$ & $63 \cdot 4$ & $60 \cdot 5$ & $61 \cdot 7$ & $61 \cdot 5$ & \\
\hline $\begin{array}{r}\% \text { change } \\
\text { Ascending NAP }\end{array}$ & . & . & . & . & . & . & . & -1 & -7 & -5 & -1 & 0 & -5 & \\
\hline - initial & .. & .. & .. & . & $\cdots$ & $\cdots$ & .. & $77 \cdot 0$ & - & $79 \cdot 5$ & $70 \cdot 3$ & - & $73 \cdot 7$ & \\
\hline - final & . & .. & . & . & .. & . & . & $73 \cdot 4$ & $91 \cdot 8$ & $75 \cdot 4$ & $71 \cdot 4$ & $71 \cdot 6$ & $75 \cdot 1$ & \\
\hline$\%$ change & . & .. & . & . & .. & .. & .. & -5 & - & -5 & +2 & - & +2 & \\
\hline
\end{tabular}

NAP $=$ nerve action potential. 

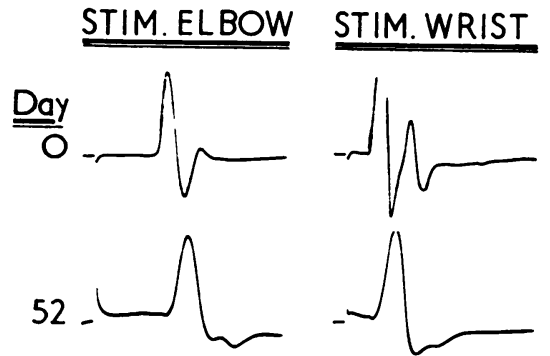

52
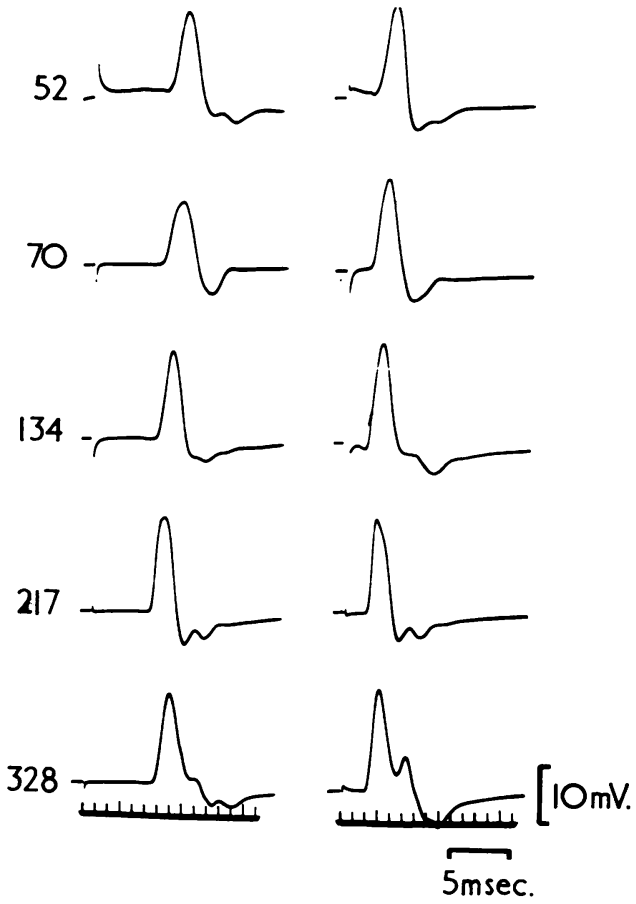

FIG. 5. Baboon 5. Muscle action potentials recorded from abductor pollicis brevis at intervals during intoxication with lead carbonate.

innervated muscles on five occasions (baboon 1, days 94 and 105; baboon 5, days 52, 70 and 134). No abnormality was found.

A search was made for fibrillation potentials in at least three muscles on each examination. No spontaneous fibrillation or positive sharp waves were seen, and insertion activity usually died away within 5 to 10 seconds of moving the needle.

The three infant baboons

EFTin

Loss of weight was observed in all three animals, which became progressively more wasted and timid. Baboon 13 was observed to drag both hind limbs for 10 days before death, but when allowed to run free it could assume the quadripedal posture briefly. The hands appeared to be used normally. No fits were witnessed in any infant. The haemoglobin was depressed to 66 and $79 \%$ of its initial level in baboons 14 and 15. It was not observed to be depressed five weeks before death in baboon 13, but at this time the animal was still gaining weight. In general it appears that the infants failed to support elevation of the blood lead of a degree comparable to those produced in the 'adults'. Baboon 13 died with the blood lead at its highest of $178 \mu \mathrm{g} / 100 \mathrm{ml}$. Baboon 14 lost a third of its body weight although the blood lead had never risen above $230 \mu \mathrm{g} / 100 \mathrm{ml}$. As in the adults, no lead line was observed and punctate basophilia was not found.

\section{Histological observations}

The results of histological observations on the brain and spinal cords and peripheral nerves of the affected animals will be reported in detail elsewhere. However, preliminary examination of the peripheral nerves and spinal cords has not so far revealed any abnormality.

\section{Discussion}

Lead failed to produce any clinical, electrophysiological or histological evidence of damage to the peripheral nerves of 15 baboons, in spite of very high levels of blood lead for periods extending up to one year. This was a surprising result in view of the isolated reports of illnesses occurring in caged primates in zoological gardens in which the illness was attributed to lead. Fisher (1954) reported a Gorilla gorilla which ate a tin of red lead paint and later developed weakness of both arms and one leg. De Bisschop, cited by Ruch (1959), described progressive quadriparesis occurring in a Gorilla gorilla, with punctate basophilia in the peripheral blood and $24 \mathrm{mg}$ lead/litre of urine. The cubital and median nerve trunks were inexcitable on electrical stimulation. One year before the cage had been painted with white lead paint. Hausman, Sturtevant, and Wilson (1961) described an orang-utan (Pongo pygmeus) in which paresis of both legs progressed over 12 days to involve both arms. The animal was killed 14 days after the onset of both symptoms. The clinical impression was that of a Guillain-Barré syndrome. The spinal cord showed posterolateral demyelination, but the peripheral nerves were not examined. Equal portions of liver and kidney analysed together contained $0.189 \mathrm{mg}$ lead/100 g wet tissue. On examination of the cage 12 roach hives were found, each containing about $300 \mathrm{mg}$ of lead arsenate. The same authors describe the case of a young female Mandrillus sphinx which developed convulsions nine weeks after first being exhibited. Two days later a left wrist-drop was noted, and after seven days the animal became blind and remained blind until its death four months later. Punctate basophilia was noted in the peripheral blood. The liver contained $1.16 \mathrm{mg}$ of lead per $100 \mathrm{~g}$ wet tissue. The nervous system was not examined histologically. The paint from the cage was found to contain $5.5 \%$ lead oxide. 
There are only two previous studies on lead poisoned primates. Ferraro and Hernandez (1932) administered lead carbonate to two 'monkeys' for 66 days as part of a larger study on the neuropathological changes in lead poisoned cats. In the brachial plexus and sciatic nerve of each animal there was 'a certain amount of segmental degeneration of nerve fibres with swelling and fragmentation of both myelin and axis cylinders. Numerous fibres were seen surrounded by a swollen myelin covering'. However, from their illustrations it does not seem that these authors are describing segmental demyelination in the sense used by Gombault (1880). Vermande van Eck and Meigs (1960) studied abnormalities of ovarian function in $M$. rhesus poisoned by weekly injections of intravenous lead chloride. They noted that one animal developed a lateral popliteal palsy, but the nervous system was not examined.

Table 1 shows that there was no significant fall in conduction velocity in six animals, two of which were followed for almost a year. There can be no question that at least four of these animals were seriously poisoned (B1, 3, 4 and 12) because they convulsed at some stage. Fullerton (1966) found a reduced conduction velocity in only 1 out of 6 guinea-pigs poisoned for 9 to 15 weeks, and in only 5 out of 18 guinea-pigs poisoned for 16 to 22 weeks. It might be suggested that chance alone precluded the finding of a reduced conduction velocity in the six baboons examined for between 13 and 50 weeks. Moreover, Fullerton points out that in a number of animals with normal conduction velocity many fibres were undergoing segmental demyelination or remyelination. The survival of only a few normal fibres will preserve motor conduction velocity. However, sensory nerve action potentials were recorded in the present study. The amplitude of these depends upon the arrival of a nearly synchronous volley beneath the recording electrode. In none of the lead poisoned baboons was there any significant reduction in the amplitude of the sensory action potential, indicating that in few, if any, of the fibres was velocity slowed.

Wallerian-type degeneration in some fibres would not produce any slowing of conduction velocity; however, interruption of the axon and its severance from the muscle fibre would cause spontaneous fibrillation. A search of many muscles, proximal and distal, and of those innervated by the radial nerve, failed to disclose any spontaneous fibrillation.

The electrophysiological findings alone suggested that the peripheral nerves were unaffected and this has been supported by a preliminary histological examination.

The present study does not suggest that there is any 'threshold' level of blood lead above which evidence of intoxication will occur. Some animals developed seizures and died with levels between
5 and 10 times less than those seen in animals which survived and maintained their weight for up to a year. This is in accord with a statement of Cantarow and Trumper (1944) that 'the concentration of lead in the blood bears no consistent relationship to the appearance or severity of clinical manifestations of lead poisoning. The latter may be absent at high levels of blood lead, and may be present at low levels'.

Anaemia and punctate basophilia were not seen in the large baboons, even in those animals which were clinically poisoned or had very high levels of blood lead.

The anaemia of lead poisoning is usually attributed to defective haemoglobinization with increased mechanical fragility, although osmotic fragility is usually a little decreased. Aub, Fairhall, Minot, and Reznikoff (1925) found that the osmotic fragility of red cells in a saline solution containing $1,000 \mu \mathrm{g}$ of lead per $100 \mathrm{ml}$ was decreased for the cells of man, rabbits, guinea-pigs and rats - species in which punctate basophilia is easily produced. There was no change in the osmotic fragility of leaded cells of horses, dogs or cats, animals which do not develop punctate basophilia or anaemia. There is clearly a difference between genera, but the occurrence of punctate basophilia in the blood of lead poisoned humans, the Gorilla cited by Ruch (1959) and the Mandrillus sphinx described by Hausman et al. (1961) makes its absence in the baboon rather surprising. There are at least two possible explanations. Stippling may not occur in the baboon because the metabolism of red cell production is different in the baboon, cat and hen from the rabbit, guinea-pig and man; or the stippled cells could be removed from the circulation as soon as they are formed.

Although a considerable amount is now known about the effect of lead on the condensation of two molecules of $\delta$-aminolevulinic acid to form porphobilinogen, and on the incorporation of iron into the protoporphyrin molecule to form haem (see Waldron, 1966, for references) there is no information available about the varying effect of lead on porphyrin metabolism in various animals.

Stippled cells are possibly removed from the circulation by the spleen. McFadzean and Davis (1949) showed that splenectomy performed on lead poisoned guinea-pigs enormously increased the numbers of circulating stippled cells, though having no quantitative effect on the stippling of the red cell precursors in the bone marrows. An alternative action of the spleen might be to remove the basophilic granules whilst leaving the red cell as a whole intact, or to stimulate the red cells to metabolize the granules rapidly. Although seemingly unlikely, the work of Crosby (1957) suggests that this is possible. He transfused chromium-51 tagged red 
cells containing siderin granules into four recipients with spleens. The siderin granules rapidly disappeared whilst the red cells remained. In two recipients after splenectomy siderin granules and cells remained in the same proportion. This explanation seems unlikely to account for the results of McFadzean and Davis as the anaemia of the guinea-pigs was also ameliorated by splenectomy.

The absence of punctate basophilia in the lead poisoned baboons might be due to an unusual path of red cell formation and haemoglobinization or to an extremely active reticulo-endothelial system which is able to remove the stippled cells or granules, or to stimulate metabolism of the granules as rapidly as they are formed (Crosby, 1957). It would be interesting to search for basophilic stippling in the bone marrow of species which fail to show it in the peripheral blood when poisoned by lead. If present in the marrow, then the most likely explanation of its absence in the blood would be rapid removal of affected cells or granules by the reticulo-endothelial system.

It might be suggested that the failure to produce lead palsy or histological and electrophysiological changes in the peripheral nerves is linked to the failure to produce anaemia and punctate basophilia. For example, the enzyme systems both of neurones and of red cells of resistant species might have features in common which allow normal function in the presence of lead. However, examination of the available data does not support this hypothesis (Table 2). In the guinea-pig, anaemia and punctate basophilia are present, and predominantly segmental demyelination occurs, mixed with some Wallerian-type degeneration (Gombault, 1880; Fullerton, 1966). In the rabbit, anaemia and punctate basophilia are present (Key, 1924), but segmental demyelination is not seen. Shimazono (1914) described Wallerian-type degeneration in lead poisoned rabbits, and de Villaverde $(1926 \mathrm{a}, \mathrm{b})$ described interruption of the axon, or at least of the argentophilic substance, which was not always accompanied by breakdown of myelin. He also stated that the anterior horn cells were shrunken, and that the Nissl granules disappeared. De Villaverde (1930) specifically stated that segmental demyelination was very rare in lead poisoned rabbits. In the rat, anaemia and punctate basophiliaare readily produced, but it is very difficult to produce more than the most scanty Wallerian-type degeneration (Prevost and Binet, 1889). In the cat, Goadby (1909) found it easy to produce extensor paralysis by exposure to litharge dust. Ferraro and Hernandez (1932) produced a little segmental demyelination and Wallerian-type degeneration in lead poisoned cats, and Lehmann, Spatz, and Wisbaum-Neubürger (1926) described extensive changes in the anterior horn cells. However, punctate basophilia and anaemia are not found in the cat. Little work has been carried out in the dog, but again there is a

TABLE 2

The Effect of Lead Poisoning in Different Species

\begin{tabular}{|c|c|c|c|c|c|c|c|c|c|}
\hline \multicolumn{4}{|c|}{ Species } & \multirow{2}{*}{\begin{tabular}{|c}
$\begin{array}{c}\text { Anaemia } \\
\text { and } \\
\text { punctate } \\
\text { basophilia }\end{array}$ \\
$\begin{array}{c}+(1) \\
++(1)\end{array}$ \\
\end{tabular}} & \multirow{2}{*}{$\begin{array}{l}\text { Encephalopathy } \\
\begin{array}{c} \\
\begin{array}{c}++(3) \\
++(4)\end{array}\end{array}\end{array}$} & Palsy & \multirow{2}{*}{$\begin{array}{c}\begin{array}{c}\text { Changes in } \\
\text { anterior } \\
\text { horn cell }\end{array} \\
+(14) \\
0 \text { (4) }\end{array}$} & \multirow{2}{*}{$\begin{array}{c}\begin{array}{c}\text { Wallerian-type } \\
\text { degeneration }\end{array} \\
+(17) \\
+(10)\end{array}$} & \multirow{2}{*}{$\begin{array}{c}\begin{array}{c}\text { Segmental } \\
\text { demyelination }\end{array} \\
\begin{array}{c}0 \\
++(10,20)\end{array}\end{array}$} \\
\hline $\begin{array}{l}\text { Man } \\
\text { Guinea-pi }\end{array}$ & & $\begin{array}{l}\ldots \\
\ldots\end{array}$ & $\begin{array}{l}\ldots \\
\ldots\end{array}$ & & & $\begin{array}{r}++(9) \\
+\quad(4) \\
.+(10)\end{array}$ & & & \\
\hline Rabbit & . & . & . & $++(1)$ & $+(5)$ & $\begin{array}{r}0(10) \\
+(11)\end{array}$ & $+(15)$ & & $\begin{array}{r}0(18) \\
\text { Very rare (21) }\end{array}$ \\
\hline Rat & . & . & . & $+(1)$ & $\begin{array}{r}+(6) \\
\text { (infants) }\end{array}$ & Trace (10) & & Rare (10) & $0(4,10)$ \\
\hline $\begin{array}{l}\text { Baboon } \\
\text { Dog } \\
\text { Cat }\end{array}$ & $\begin{array}{l}\cdots \\
\cdots \\
\cdots\end{array}$ & $\begin{array}{l}. . \\
\cdots \\
.\end{array}$ & $\begin{array}{l}. . \\
\ldots \\
. .\end{array}$ & $\begin{array}{l}0(2) \\
0(1) \\
0(1)\end{array}$ & $\begin{array}{l}++(2) \\
++(7) \\
++(8)\end{array}$ & $\begin{array}{r}\text { Postictal (2) } \\
+(12) \\
++\quad(13)\end{array}$ & $\begin{array}{r}0(2) \\
+(16) \\
++(8)\end{array}$ & $\begin{array}{r}0(2) \\
\text { Rare (12) } \\
+(19) \\
0(8)\end{array}$ & $\begin{array}{r}0(2) \\
+(19)\end{array}$ \\
\hline
\end{tabular}

The numbers in the table relate to the references listed below:

1. Aub, Fairhall, Minot, and Reznikoff (1925)

2. Present study

3. Grisolle (1836)

4. Fullerton (1966)

5. Roberti (1931)

6. Pentschew and Garro (1966)

7. Combemale and Francois (1890)

8. Lehmann, Spatz and Wisbaum-Neubürger (1926)

9. Tanquerel des Planches (1839)

10. Prevost and Binet (1889)
11. de Villaverde (1926a)

12. Lugaro (1897)

13. Goadby (1909)

14. Herter (1895)

15. Nissl (1892)

16. Catalano (1906)

17. Gombault (1873)

18. Shimazono (1914)

19. Ferraro and Hernandez (1932)

20. Gombault (1880)

21. de Villaverde (1930) 
dissociation between the occurrence of encephalopathy and histological changes and the absence of changes in the blood. In the baboon it was not possible to produce any clinical or electrophysiological evidence of damage to the peripheral nervous system, and this has been supported by preliminary histological examination; neither was anaemia or punctate basophilia produced, yet encephalopathy was common.

Punctate basophilia and anaemia occurs readily in lead poisoned man, and pathological changes have been described in the spinal cord and peripheral nerves. Gombault (1873), in the case report of a woman colourer who developed wrist drop, described extensive Wallerian-type degeneration, as did Dejerine (1879). The spinal cord in Gombault's report was normal. Herter (1895) described extensive changes in the spinal cord of a 26-year-old man with wrist drop, colic and encephalopathy. He estimated that up to one third of the anterior horn cells showed disintegration of the chromophil granules, vacuolization and pigmentation. Approximately one fibre in four of the lateral popliteal nerve was undergoing Wallerian-type degeneration. Essentially similar findings were reported by Laslett and Warrington (1898) and by other authors. Laslett and Warrington teased fibres but failed to find any evidence of segmental demyelination.

These findings in various species, which are summarized in Table 2, do not throw any light on the metabolic lesions produced by lead in the red cell precursors and in the neurone or Schwann cell. Moreover, even in those animals with clear histological lesions in the central or peripheral nervous system there is an obvious difference between those species like the guinea-pig and rabbit, which develop a mild paresis in spite of extensive lesions in the peripheral nerves, and the human situation in which a sudden severe palsy may occur, with relatively slight changes in the peripheral nerves.

The present work was carried out while the author was in receipt of a grant from the Medical Research Council, which is gratefully acknowledged.

I thank Professor R. W. Gilliatt for his help and guidance during this work. Mr. T. Delves kindly estimated the blood lead of the baboons.

The results reported here formed a part of a thesis submitted for the degree of Doctor of Medicine of the University of London.

\section{References}

Aub, J. C., Fairhall, L. T., Minot, A. S., and Reznikoff, P. (1925). Lead poisoning. Medicine (Baltimore), 4, 1-250.

Cantarow, H., and Trumper, M. (1944). Lead Poisoning. Williams and Wilkins, Baltimore

Catalano, G. (1906). Alterazioni anatomo - patologiche del sistema nervosa nell' avvelenamento sperimentale cronico da piembo. Policlinico sez. med., 13, 324-332.

Combemale and François (1890). Recherches expérimentales sur les troubles nerveux du saturnisme chronique et sur les causes déterminantes de leur apparition. C.R. Acad. Sci. (Paris), 111 276-278.

Crosby, W. H. (1957). Siderocytes and the spleen. Blood, 12, 165-170.

Dejerine, J. (1879). Recherches sur les lésions du système nerveux dans la paralysie saturnine. C.R. Soc. Biol. (Paris), 7th ser., 1, Mém., pp. 11-17.

Delves, H. T., and Vinter, P. (1966). Semi-automatic determination of lead in whole blood. J. clin. Path., 19, 504-509.

Delwaide, P. J., and Chantraine, J. M. (1965). Participation spinale dans l'intoxication Saturnine: arguments electromyographiques. Proc. 6th International Congress of Electroencephalography and Clinical Neurophysiology, Vienna 1965. p. 643-646.

Ferraro, A., and Hernandez, R. (1932). Lead poisoning. (A histopathological study of the nervous system of cats and monkeys in the acute and subacute stages.) Psychiat. Quart., 6, 121-146, 319-350.

Fisher, L. E. (1954). Lead poisoning in a gorilla. J. Amer. vet. med. Ass., 125, 478-479.

Fullerton, P. M. (1966). Chronic peripheral neuropathy produced by lead poisoning in guinea-pigs. J. Neuropath. exp. Neurol., 25, 214-236.

Goadby, K. (1909). A note on experimental lead poisoning. J. Hyg. (Lond.), 9, 122-133.

Gombault, A. (1873). Contribution à l'histoire anatomique de l'atrophie musculaire saturnine. Arch. Physiol. norm. path., 5, 592-597.

- (1880). Contribution à l'étude anatomique de la névrite parenchymateuse subaiguë et chronique - névrite segmentaire péri-axile. Arch. Neurol. (Paris), 1, 11-38.

Grisolle, A. (1836). Recherches sur Quelques-uns des Accidents Cérébraux Produits par les Préparations Saturnines. Paris.

Hausman, R., Sturtevant, R. A., and Wilson, W. J. (1961). Lead intoxication in primates. J. forens. Sci., 6, 180-96.

Hausmanowa-Petrusewicz, I, Emeryk, B., Sobkowicz, H., Wasowicz, B., and Tur, J. (1962). Badania elektromiograficzne $w$ ołowicy. [Electromyographic studies in lead poisoning.] Polski Tyg. lek., 17, 1405-1408.

Herter, C. A. (1895). Report of a case of lead paralysis, with special reference to cytological changes in the nervous system and the distribution of the lead. N.Y. med.J., 61, 665-667.

Hopkins, A. P. (1968). Experimental neuropathy in the baboon. M.D. thesis, University of London.

Key, J. A. (1924). Lead studies. IV. Blood changes in lead poisoning in rabbits, with especial reference to the stippled cells. Amer. $J$. Physiol., 70, 86-99.

Laslett, E. E., and Warrington, W. B. (1898). The morbid anatomy of a case of lead paralysis. Condition of the nerves, muscles, muscle spindles and spinal cord. Brain, 21, 224-231.

Lehmann, K. B., Spatz, H., and Wisbaum-Neubürger, K. (1926). Die histologischen Veränderungen des Zentralnervensysteme bei der bleivergifteten Katze und deren Zusammenhang mit den klinischen Erscheinungen insbesondere mit Krampfanfällen. Z. ges. Neurol. Psychiat., 103, 323-360.

Lugaro, E. (1897). Sulle alterazioni degli elementi nervosi negli avvelenamenti per arsenico e per piombo. Riv. Pat. nerv. ment., 2, 49-64.

McFadzean, A. J. S., and Davis, L. J. (1949). On the nature and significance of stippling in lead poisoning, with reference to the effect of splenectomy. Quart. J. Med., 42 (n.s. 18), 57-72.

McLeod, J. G., and Wray, S. H. (1967). Conduction velocity and fibre diameter of the median and ulnar nerves of the baboon. J. Neurol. Neurosurg. Psychiat., 30, 240-247.

Minot, A. S. (1924). Lead studies. V.B. The distribution of lead in the organism after absorption by the lungs and subcutaneous tissue. J. industr. Hyg., 6, 137-148.

Nissl, F. (1892). Ueber experimentell erzeugte Veränderungen an den Vorderhornzellen des Rückenmarks bei Kaninchen mit Demonstration mikroskopischer Präparate. Allg. Z. Psychiat., 48, 675-682.

Oxnard, C. E., and Smith, W. T. (1966). Neurological degeneration and reduced serum vitamin $\mathbf{B}_{12}$-levels in captive monkeys. Nature (Lond.), 210, 507-509.

Pentschew, A., and Garro, F. (1966). Lead encephalo-myelopathy of the suckling rat and its implications on the porphyriopathic nervous diseases, with special reference to the permeability disorders of the nervous system's capillaries. Acta neuropath. (Berl.), 6, 266-278.

Preiskel, D. (1958). Chronic lead poisoning: myopathy or neuritis? Ann. phys. Med., 4, 293-296.

Prevost, J. L., and Binet, P. (1889). Recherches expérimentales sur l'intoxication saturnine. Rev. méd. Suisse rom., 9, 606-623. 
Roberti, C. E. (1931). Sul comportamento della macroglia o degli elementi nervosi nelle intossocazioni sperimentali da: istammina, guanidina, acido cloridrico, acetato di piombi e acetato talloso. Rass. Studi psichiat., $20,7$.

Ruch, T. C. (1959). Diseases of Laboratory Primates. The Handbook of the Primates, Part 1. Saunders, Philadelphia and London.

Sessa, T., Ferrari, E., and Colucci D'Amato, C. (1965). Velocità di conduzione nervosa nei saturnini. Folia med. (Napoli), 48, 658-668.

Shimazono, J. (1914). Ueber das Verhalten der zentralen und der peripheren Nervensubstanz bei verschiedenen Vergiftungen und Ernährungsstörungen. Arch. Psychiat. Nervenkr., 53, 972-1094.

Simpson, J. A., Seaton, D. A., and Adams, J. F. (1964). Response to treatment with chelating agents of anaemia, chronic encephalopathy, and myelopathy due to lead poisoning. J. Neurol. Neurosurg. Psychiat., 27, 536-541.

Tanquerel des Planches, L. (1839). Traité des Maladies de Plomb ou Saturnines. Forra, Paris.

Vermande-Van Eck, G. J. and Meigs, J. W. (1960). Changes in the ovary of the rhesus monkey after chronic lead intoxication. Fertil. and Steril., 11, 223-234.

de Villaverde, J. M. (1926a). Les résultats tardifs de l'intoxication saturnine expérimentale des nerfs. Trab. Lab. Invest. biol. Univ. Madr., 24, 155-179.

- (1926b). Lésions des nerfs dans l'intoxication saturnine expérimentale. Trab. Lab. Invest. biol. Univ. Madr., 24, 1-52.

(1930). Sur l'avenir des parties const itutives de la fibre nerveuse dans l'intoxication expérimentale par le plomb. Trav. Lab. Invest. biol. Univ. Madr., 26, 163-187.

Waldron, H. A. (1966). The anaemia of lead poisoning: a review Brit. J. industr. Med., 23, 83-100.

Williams, M. K. (1966). Blood lead and haemoglobin in lead absorption. Brit. J. industr. Med.. 23, 105-111.

\section{Baboon 1}

\section{Appendix}

Female $13 \cdot 4$ kg. 5,700 mg of $\mathrm{PbCO}_{3}$ given in 6 injections. $25 \%$ loss of weight by day 63 . First fit day 94,2 nd fit day 98. On day 99 noted to have definite weakness and clumsiness of the left hand when taking pellets out of the feeding bin. The grip round a rod was observed to be weak. Left leg normal. Weakness persisted to death, after further observed fits on day 107 . Final weight only $58 \%$ of initial weight. Highest blood lead $6,200 \mu \mathrm{g} / 100$ $\mathrm{ml}$.

\section{Baboon 2}

Anubis, female $11 \cdot 2 \mathrm{~kg} .4,000 \mathrm{mg}$ of $\mathrm{PbCO}_{3}$ given in 4 injections. $\mathrm{Hb}$ dropped to $40 \%$ of initial value by day 43 , but occult blood found in stools, and $\mathrm{Hb}$ returned to near initial value before death in status epilepticus on day 72 . Final weight $73 \%$ of initial weight; highest blood lead $3,300 \mu \mathrm{g} / 100 \mathrm{ml}$.

\section{Baboon 3}

Anubis, female $11 \cdot 7 \mathrm{~kg}$. $6,200 \mathrm{mg}$ of $\mathrm{PbCO}_{3}$ given in 6 injections. First fit day 148, beginning in the right face followed by a postictal paresis lasting 15 minutes. Very savage between fits. Died in status epilepticus on day 156 ; final weight $64 \%$ of initial weight; highest blood lead $1,780 \mu \mathrm{g} / 100 \mathrm{ml}$.

\section{Baboon 4}

Anubis, female $10 \cdot 7 \mathrm{~kg} .7,800 \mathrm{mg}$ of $\mathrm{PbCO}_{3}$ given in 8 injections. First fit day 95, others followed. Pneumonic illness began day 256; treated with sulphadimidine; seen to die a pneumonic death on day 265. Empyema found at autopsy. Final weight $66 \%$ of initial weight; highest blood lead $1,150 \mu \mathrm{g} / 100 \mathrm{ml}$.

\section{Baboon 5}

Anubis, female $13 \cdot 6 \mathrm{~kg}$. 9,700 mg of $\mathrm{PbCO}_{3}$ given in 11 injections. General condition remained very good. Sacrificed day 336. Final weight $88 \%$ of initial weight; highest blood lead 4,550 $\mu \mathrm{g} / 100 \mathrm{ml}$.

\section{Baboon 6}

Anubis, female $12.0 \mathrm{~kg}$. $12,700 \mathrm{mg}$ of $\mathrm{PbCO}_{3}$ given in 13 injections. No fits. General condition remained very good. Sacrificed day 362 . Final weight $100 \%$ of initial weight; highest blood lead 2,200 $\mu \mathrm{g} / 100 \mathrm{ml}$.

\section{Baboon 7}

Anubis, female $11 \cdot 1 \mathrm{~kg} .3,200 \mathrm{mg}$ of $\mathrm{PbCO}_{3}$ given in 3 injections. Welland active, though increasingly aggressive, until sudden death day 123 . Final weight $54 \%$ of initial weight; highest blood lead 1,500 $\mu \mathrm{g} / 100 \mathrm{ml}$.

\section{Baboon 8}

Anubis, female $11 \cdot 8 \mathrm{~kg} .4,500 \mathrm{mg}$ of $\mathrm{PbCO}_{3}$ given in 5 injections. Jaundiced day 77; serum bilirubin $2.0 \mathrm{mg} / 10$ $\mathrm{ml}$, alkaline phosphatase 445 I.U./litre. No longer jaundiced 4 days later. Found dead day 107 . Final weight $62 \%$ of initial weight; highest blood lead $725 \mu \mathrm{g} / 100 \mathrm{ml}$. Autopsy showed hepatic centrilobular necrosis.

Baboon 9

Anubis, female $11.8 \mathrm{~kg}$. $3,000 \mathrm{mg}$ of $\mathrm{PbCO}_{3}$ given in 3 injections. Well until sudden death after one fit on day 61. Final weight $70 \%$ of initial weight; highest blood lead $700 \mu \mathrm{g} / 100 \mathrm{ml}$.

\section{Baboon 10}

Anubis, male $7 \cdot 2 \mathrm{~kg}$. $1,250 \mathrm{mg}$ of $\mathrm{PbCO}_{3}$ given in 2 injections. Bloody diarrhoea day 39 (another control baboon also affected at this time). Died day 39. Autopsy showed haemorrhagic colitis. Final weight $77 \%$ of initial weight; highest blood lead $1,100 \mu \mathrm{g} / 100 \mathrm{ml}$.

\section{Baboon 11}

Anubis, male $8.6 \mathrm{~kg} .4,800 \mathrm{mg}$ of $\mathrm{PbCO}_{3}$ given in 5 injections. First fit day 102, followed by others. Died in status epilepticus day 106 . Final weight $58 \%$ of initial weight; highest blood lead $500 \mu \mathrm{g} / 100 \mathrm{ml}$.

\section{Baboon 12}

Anubis, male $9 \cdot 5 \mathrm{~kg} .4,200 \mathrm{mg}$ of $\mathrm{PbCO}_{3}$ given in 5 injections. Day 138, apparent weakness of hind limbs preventing the animal rising in its cage. Day 139, a series of grand mal fits observed, without recovery of consciousness between. Phenobarbitone, $30 \mathrm{mg}$, given intramuscularly. No further fits observed for 14 days, but flaccid quadriparesis continued, affecting left limbs more than the right. When the baboon was allowed to walk free the legs became splayed or crossed. Left fingers unable to grasp orange segments. On day 150 the animal was examined in a restraining chair. Voluntary movement present in all 4 limbs, with brisk withdrawal from pinprick. Knee jerks brisk, plantar responses flexor. Systolic B.P. $90 \mathrm{~mm} \mathrm{Hg}$. From day 139 to death on day 158 a visual disturbance was seen - the animal groped for proffered fruit and on occasions appeared not to see it. Marked papilloedema was observed before death. Final weight $60 \%$ of initial weight; highest blood lead $630 \mu \mathrm{g} / 100 \mathrm{ml}$. 


\section{Baboon 13}

Anubis, female $2 \cdot 8 \mathrm{~kg}$, infant of baboon $7.2,150 \mathrm{mg}$ of $\mathrm{PbCO}_{3}$ given in 4 injections. Apparently dragging hindquarters day 107. Found dead day 117; final weight $61 \%$ of initial weight; highest blood lead $140 \mu \mathrm{g} / 100 \mathrm{ml}$.

\section{Baboon 14}

Hamadryas, female $2 \cdot 5 \mathrm{~kg} .1,950 \mathrm{mg}$ of $\mathrm{PbCO}_{3}$ given in 4 injections. No signs save loss of weight. Sacrificed day 150 . Final weight $68 \%$ of initial weight; highest blood lead $230 \mu \mathrm{g} / 100 \mathrm{ml}$.

\section{Baboon 15}

Hamadryas, female $3 \cdot 3 \mathrm{~kg} .2,150 \mathrm{mg}$ of $\mathrm{PbCO}_{3}$ given in 4 injections. No signs except malaise and loss of weight. Found dead in cage day 75 . Final weight $64 \%$ of initial weight; highest blood lead $560 \mu \mathrm{g} / 100 \mathrm{ml}$.

Received for publication August 28, 1969. 